\title{
Floral Organogenesis and Ring Meristem in Phytolacca
}

\author{
Hongchun Zheng1* ${ }^{*}$ Anming $\mathrm{Lu}^{2}$, Zhenghai $\mathrm{Hu}^{3}$ \\ ${ }^{1}$ Department of Biology and Technology, Shaanxi Xueqian Normal University, Xi'an, China \\ ${ }^{2}$ Institute of Botany, Chinese Academy of Science, Beijing, China \\ ${ }^{3}$ Life Science College, Northwest University, Xi'an, China \\ Email: ${ }^{*}$ chzheng@163.com
}

Received 14 December 2014; accepted 13 February 2015; published 25 February 2015

Copyright (C) 2015 by authors and Scientific Research Publishing Inc.

This work is licensed under the Creative Commons Attribution International License (CC BY). http://creativecommons.org/licenses/by/4.0/

(c) (i) Open Access

\section{Abstract}

To further study the floral organogenesis and discussing the floral origin of Phytolacca, the procedures of floral organogenesis were observed in Phytolacca esculenta and Phytolacca zhejiangensis. The results showed that the floral organogenesis was consistent in Phytolacca. Their sepals were $2 / 5$ helix, and with counter-clockwise and clockwise, usually the first sepal located at nonmedian of abaxial side. The first sepal of Phytolacca esculenta was initiated at non-median of adaxial side. There was no evident relationship between sepal and stamen initiating position, and the stamens initiated on ring meristem, they initiated approximately at the same time, and when the androecium member was numerous, they initiated centrifugally, the outer stamen initiated irregularly. Carpel initiated alternately with inner stamens. And the carpels connected by septum, if the septum grew more, the carpel was syncarpous at morphology, otherwise the carpel was apocarpous at morphology. So the syncarpous and the apocarpous have no successively relationship on evolution. Ovule initiated inside the carpel and opposite to carpel. Androecium, carpel and ovule initiated at ring meristem.

\section{Keywords}

Phytolacca, Floral Organogenesis, Stamen, Carpel, Ovule, Ring Meristem

\section{Introduction}

Phytolacca is the most original genus, is also the biggest one in Phytolaccaceae, with ca. 25 species [1] or 35 species [2]. This genus have raceme, which is acrogenous on apex, and opposite with leaf in lower (This is caused by axillary bud strongly growth). Flower has one bract and two bractlet. Sepal is 5, rarely 4 or 6, green-

${ }^{*}$ Corresponding author. 
ish white to red, quincuncial. Stamens 6 to 33, line in one whorl or numerous whorls [3]. Carpel 5 to 16, line in one whorl, their base united each other, upper separated or whole united together besides style and stigma [3]-[5].

On the sepal, there is no difference opinion, but on stamen and carpel have 3 opinions: 1) the androecium is out ring opposite with sepal [3] [6]-[9], this opinion also is supported by Leins [10] [11]; 2) the reports of organogenesis show that androecium developed centrifugally when it is polystemonous. This was proved by Ronse Decreane [12], and at same time he thought the outer arising centrifugal stamens were not the result of a secondary multiplication, and this character maybe the basal feature of Caryophyllales [12]; 3) Ronse Decreane and Smets [13] [14] suggested that pentamerous flower of Caryophyllales may well have been derived from a trimerous prototype by a contraction of two perianth whorls and the subsequent loss of stamens at the point of fusion of two sepals [13] [14]. Ronse Decreane (1997) through observing four species organogenesis of Phytolacca supported this opinion furthermore [12].

Ring meristem is very important tissue, but its characters on flower organs formation are unknown. The significance of ring meristem never was discussed. And the relationship of ring meristem and apex meristem never is considered. In plants evolution, what significance is ring meristem formation? Stamen, carpel, and ovule are same production of ring meristem or not? Did ovule originate from ring meristem or not? In this paper, these problems will be discussed.

Evidently there are some arguments on its androecium. As an original group, Phytolacca's androecium and gynaecium almost have no any leaf traits, how did it derive from leaf? Why have they no evidently relationship with the original angiosperm? We wanted to know the initial type of its androecium, so we selected two species observed carefully, for proving whether the androecium initiated opposite with sepal or not.

Phytolacca esculenta is a species which is similar to Ph. acinosa, but its anther is red, filament is white, sepal is white, distinct from Ph. acinosa easily. Ph. zhejianensis is a species with multiple stamens, seed with fingerprint, it only distributed at Zhejiang province of China. We will accord to our result and other author's result, discuss the problems on Phytolacca.

\section{Materials and Methods}

Ph. esculenta was from Medicine Botanical Garden of Guangxi Province; Ph. zhejiangensis was from Tianmu Mountain Nature Conservation District. Materials were fixed by FAA, and conserved in FAA. The materials were dehydrated to $100 \%$ ethanol by grades ethanol, and dissected in 95\% ethanol under dissecting microscope; then they were transfer to acetone via grades ethanol-acetone, $\mathrm{CO}_{2}$ critical point dried by $\mathrm{HCP}-2$ dryness. It were gilded a gold coat by SPI-MODULE Ion-splash. It was observed by Hitachi S-800 SEM.

\section{Results}

\subsection{Sepal Initiation}

Floral primordium initiated in the axilla of bract (Figure 1(a), Figure 1(b), Figure 2(a)). Sepals of two species initiated in 2/5 helix. They initiated to heel bractlet, which also initiated in 2/5 helix; and there is no gape between the initial of sepal and bractlet. First bractlet can initiated at right or left of floral primordium (Figure 1(c), Figure 1(d)). In two species, the initiation of bractlet is slightly different. In Ph. zhejiangensis, bractlet is always initiated lean to abaxial part, but in Ph. esculenta, bractlet initiated at lean to abaxial or adaxial part (Figures 2(b)-(d) is at adaxial part and $\mathrm{E}$ is at abaxial part), they initiated in clockwise or anticlockwise. The first bractlet initiated always at the median of one side of floral primordium, the second one initiated at lean to adaxial part, so the first sepal initiated at non-median part of abaxial part, the exception occur at Ph. esculenta, its second bractlet occasionally initiated lean to abaxial part, so the first sepal initiated at the non-median of adaxial part. Then sepal initiated in clockwise or anticlockwise every 2/5 circle. The edge of earlier sepal is out, and the later is inner, at last formed a quincuncial perianth (Figures 1(b)-(i), Figures 2(b)-(g)). Before the sepals mature, they are evidently different each other in size, the earlier sepal is bigger than later, but when they mature, they were sub-equal in size. Two bractlets were narrow.

\subsection{Androecium Initiation}

After perianth initiated, the centre meristem of primordium was pentagon (Figure 2(g)), at this time, the androe- 


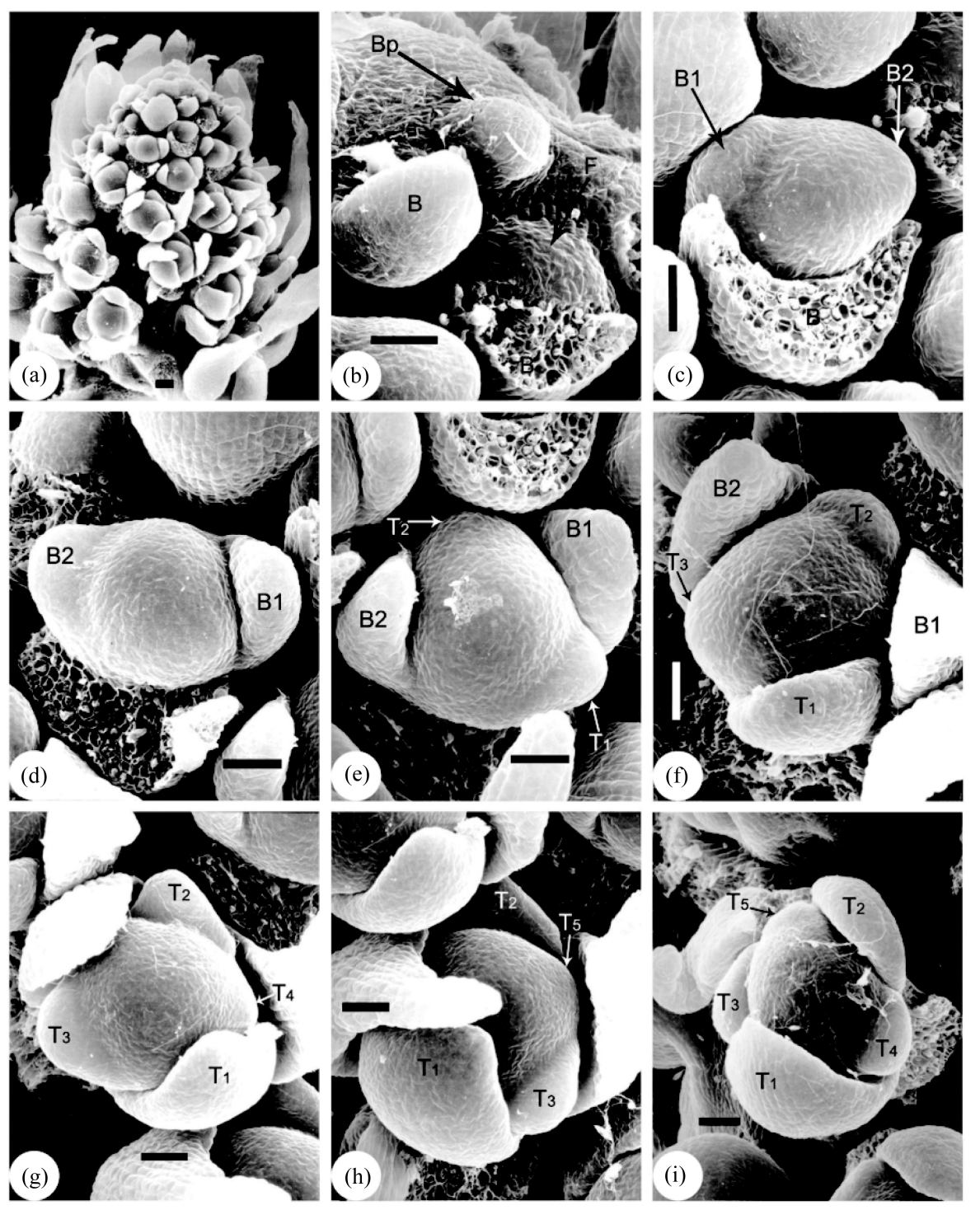

Figure 1. Initiation of bracts and sepals in Ph. zhejiangensis. (a) Developing inflorescence; (b) Initiating flower. The bract primordium initiated firstly, then the floral primordium initiated in the axilla of bract; (c) The bractlets were initiating at the two sides of floral primordium; and the left one is bigger than right one; (d) Developing bractlets, the right one is bigger than left one; (e) The first and the second sepal was initiating; (f) The third sepal is initiating; (g) The fourth sepal was initiating; (h) The fifth sepal was initiating; (i) Five sepals have initiated. B represents bract. Bp represents bract primordium. B1, B2 represents bractlet (number described the initiation order); $\mathrm{T}_{1}, \mathrm{~T}_{2}, \mathrm{~T}_{3}, \mathrm{~T}_{4}, \mathrm{~T}_{5}$ represents sepal (number described its initiation order). Bar $=50 \mu \mathrm{m}$.

cium primordium did not initiated, after a short time, the apex meristem changed to roundness (Figure 2(h)). At this time, the edge of apex meristem changed to a ring meristem. Then some small or large protuberances formed at ring meristem, these protuberances distinct each other (Figures 3(a)-(d); Figure 2(i) and Figure 4(a)), they are androecium primordium. They did not rise in sequence; there is no sequence as sepal. Two androecium primordia could be see which have similar size, also could see single large androecium primordium. And there is no evident relationship between them and sepal. Especially the size of sepal has bigger difference in size, as the sepal growing, the first and second sepals are smaller, and the later three sepals are larger. In every flower, androecium initiated almost at the edge of primordium at same time, but they are different in growing and the difference show soon after they initiated (Figure 4(a); Figure 2(i); Figure 3(c)), at last, they trended to same size 

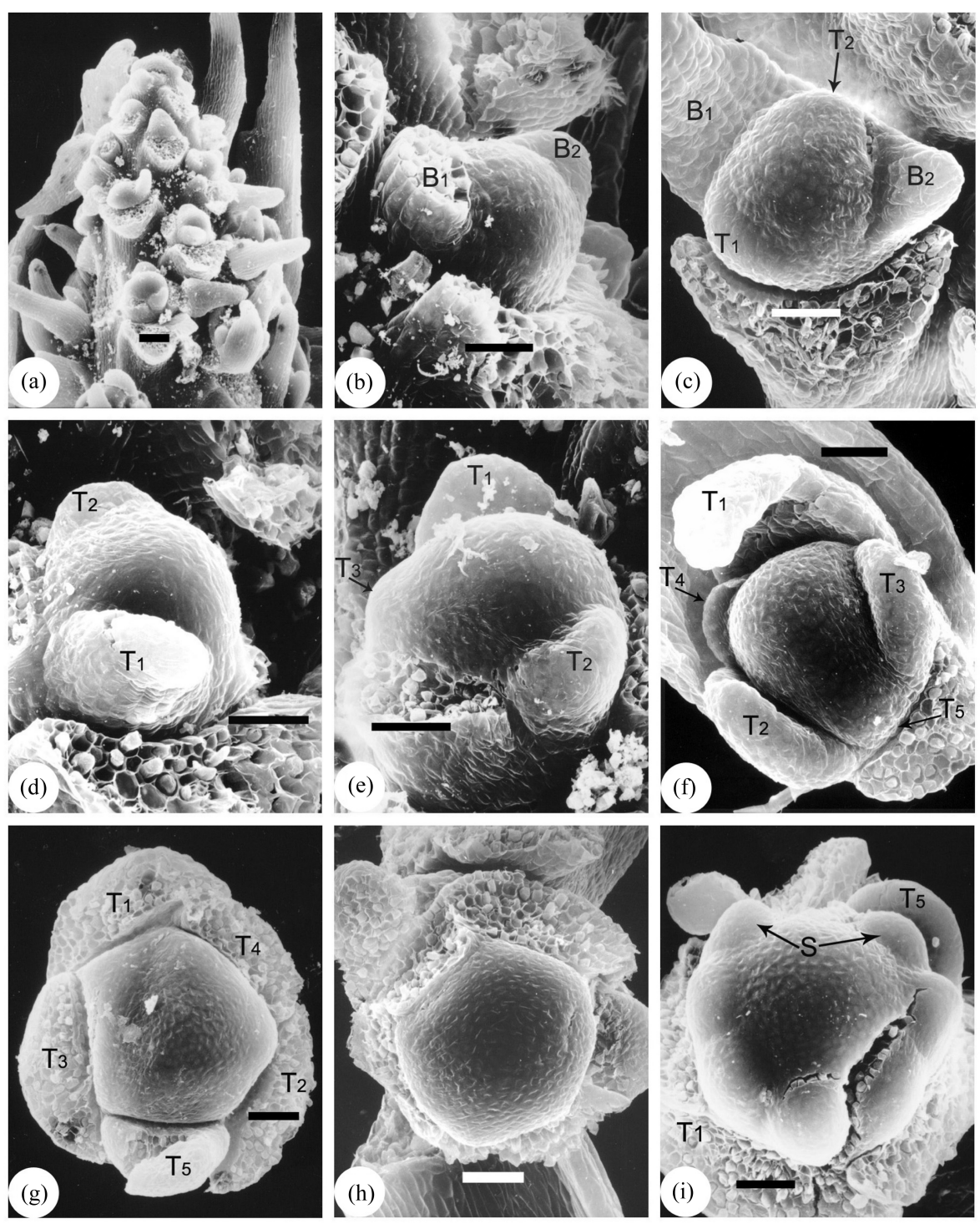

Figure 2. Sepals initiated and androecium initiated in Ph. esculenta. (a) Developing inflorescence; (b) Floral primordium with two bracts; (c) The first and second sepal initiated; (d) Floral primordium with two evident sepals; (e) The third sepal initiated; (f) The fifth sepal initiated; (g) Five sepals were formed and the apex meristem was pentagon; (h) Apex meristem changed to roundness; (i) Androecium primordia were forming on ring meristem (the edge of apex meristem). $B_{1}, B_{2}$ represents bract (number described the initiation order); $T_{1}, T_{2}, T_{3}, T_{4}$, $T_{5}$ represents sepal (number described its initiation order). S represents stamen. Bar $=50 \mu \mathrm{m}$.

with growing further more (Figure 4(b); Figure 3(e), Figure 3(f)). Generally stamen is 8, but it is 7 rarely (Figure 4(i)). In Ph. zhejiangensis, after the inner androecium primordium initiated, outer part continues formed androecium primordium (Figure 3(d), Figure 3(e)). The outer androecium did not initiate in sequence (Figure 3(e), Figure 3(g), Figure 3(h)), and it is 8 in most cases (Figure 5(g)). But their number may be changed sometime, so the number of androecium changed by the outer androecium in this species.

\subsection{Gynoecium Initiation}

In these two species, the carpel primordium initiated following directly on its androecium in Ph. esculenta or inner androecium in $P h$. zhejiangensis, and alternately with them. The primordium was separate; subsequently its basal tissue took part in carpel forming, so the carpel was united together as a whole in base (Figures 3(e)-(i); 

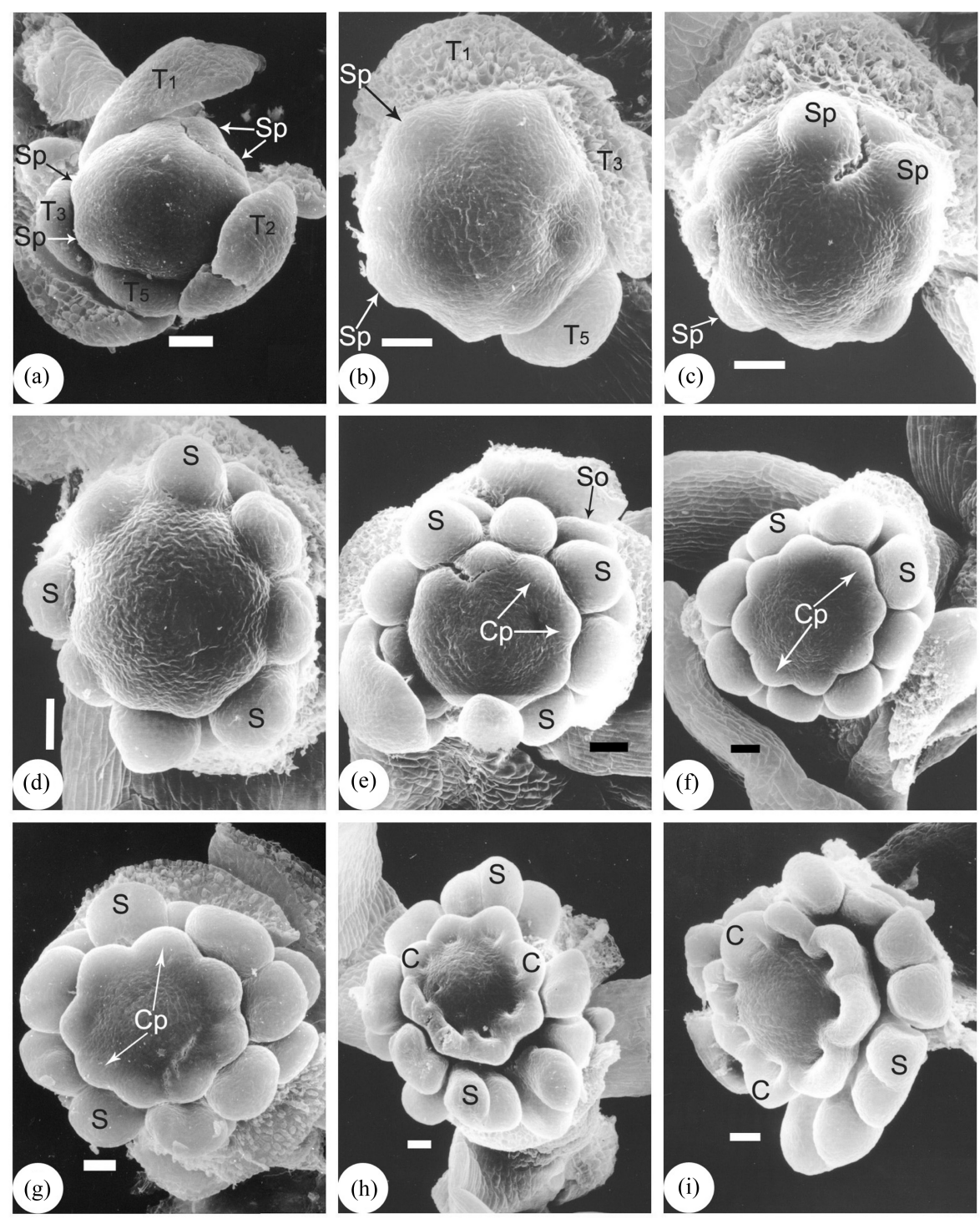

Figure 3. Initiation of androecium and capel of Ph. zhejiangensis. (a) Androecia are initiating on the edge of apex meristem (ring meristem); (b) Eight androecium primordia appeared on the ring meristem; (c) Developing androecia primordium; (d) Androecia were developing and carpels were forming; (e) Outer stamens were developing and carpel primordia were forming on the ring meristem (edge of apex meristem); (f) and (g) Stamens were developing and carpel primordia were forming and developing; (h) and (i) Carpels were developing and the ovary loculus formed at inside of carpel. Sp represents androecium primordium. $T_{1}, T_{2}$, $T_{3}, T_{4}, T_{5}$ represents sepal (number described its initiation order). So represents outer stamen. Cp represents carpel primordium. C represents Carpel. Bar $=50 \mu \mathrm{m}$.

Figures 5(a)-(d); Figure 4(b), Figure 4(c)). The primordium apex directed to outer, as gynoecium growing, it transferred to direct to top. As gynoecium primordium growing, the ring meristem of base grown at same time, and formed a ring structure which like crenelated wall. The base of gynoecium primordium developed to main part of gynoecium. The upper separate parts developed to styles and stigmas (Figure 5(e), Figure 5(f), Figure 5(h); Figures 6(a)-(d)). The basal part gradually formed ovary, which is united earlier in these two species (Figure 4(i); Figure 6(a)). In Ph. zhejiangensis the part united at all time, but in Ph. esculenta it is different, the septum between two carpel grown little, while the other part of carpel grown large, so the carpel gradually look like separate evidently. When carpel was mature, separate part was main part, so people generally thought it is separate carpel in morphology (Figures 6(b)-(e)). Carpel is 8 generally, but sometime it is 7 (Figure 5(d); 

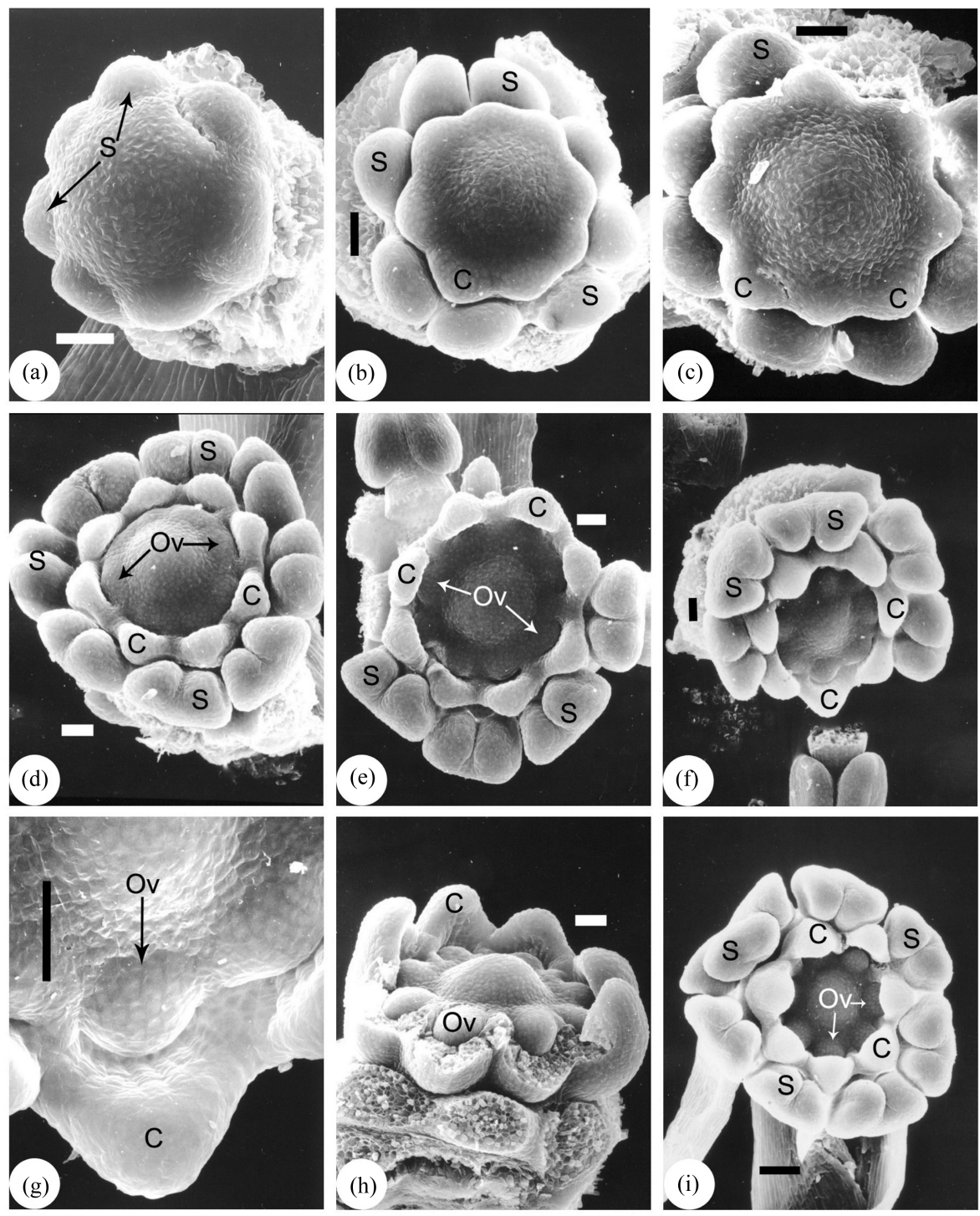

Figure 4. Initiation and development of androecia and carpels in Ph. esculenta. (a) Androecium primordia were initiating on ring meristem; (b) Carpel primordial were initiating on ring meristem; (c) Developing carpels; (d) Ovule primordia were initiating on ring meristem; (e)-(i) Carpel and ovule were developing; (g) was a part of (f) S represents stamen. C represents carpel. Ov represents ovule. Bar $=50 \mu \mathrm{m}$.

Figure 4(f), Figure 4(i)), and sometime it is 9 (Figure 5(f), Figure 5(h)).

There formed a protuberance opposite to carpel at the inner of carpel, when carpel grown to form a ring structure. This protuberance is ovule primordium (Figure 5(b); Figures 4(d)-(h)). With the carpel growing, the upper part of carpel extended to the center of floral primordium, and lay over its apex. At the same time, the septum grown to center and surround ovule. The ovule is base.

The upper part of carpel developed to style and stigma, and the stigma located at the inside of style and its face like grape (Figure 5(i); Figure 6(e), Figure 6(f)).

\section{Discussion}

\subsection{Ring Meristem and Initiation of Androecium}

It is false that genus Phytolacca outer androecium opposite with sepal. This opinion was supported by Ronse 

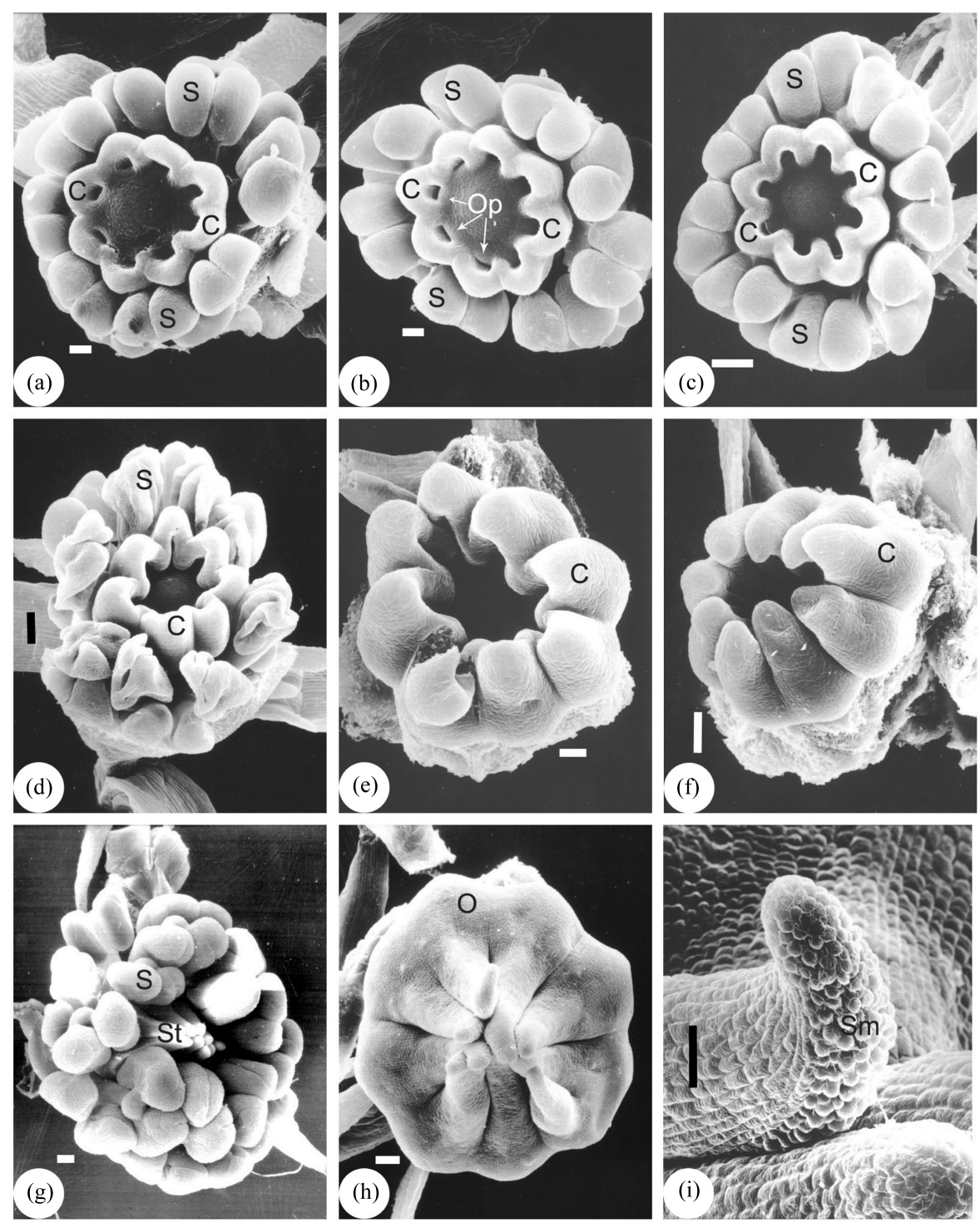

Figure 5. Pistil was developing and the mature pistil of Ph. zhejiangensis. (a) Carpels were developing and the chambers were extended; (b) The ovule primordia initiated at ring meristem (the apex meristem); (c)-(f) Carpels were developing; (g) Mature stamens and carpels; (h) Mature pistil, syngynoeciu can be seen; (i) Style and stigma. S represents stamen. C represents carpel. Op represents ovule primordium. C represents carpel. St represents style. Sm represents stigma. O represents ovary. Bar $=50 \mu \mathrm{m}$.

Decreane [12]. Whether to observe organogenesis or to observe its flower, there is no outer androecium opposite with sepal. Especially when the numerous of androecium is ten or much less, the androecium located in one whorl, so outer androecium which opposite with sepal did not present, and when the numerous of androecium is more than ten, the outer androecium also did not opposite with sepal. Although Ronse Decreane negated this opinion, but he still thought the androecium initiate in twist, and every two stamens opposite with every sepal. And this opinion also supported by Nishino and Chen Dan et al. [15] [16]. Accordance with our observation and the picture of other author, that androecium was thought initiated without regular relationship to sepal, but on ring meristem. Tucker (2003) first used ring meristem, she thought many taxa (29 families) have ring meristem [17], and she definition this concept as a continued, ring, and active center non-evident meristem. The apex meristem completely accords with ring meristem, which formed androecium in Phytolacca. There is no active center; and androecium initiated irregularly. Before androecium initiated, a pause is very important for ring meris- 

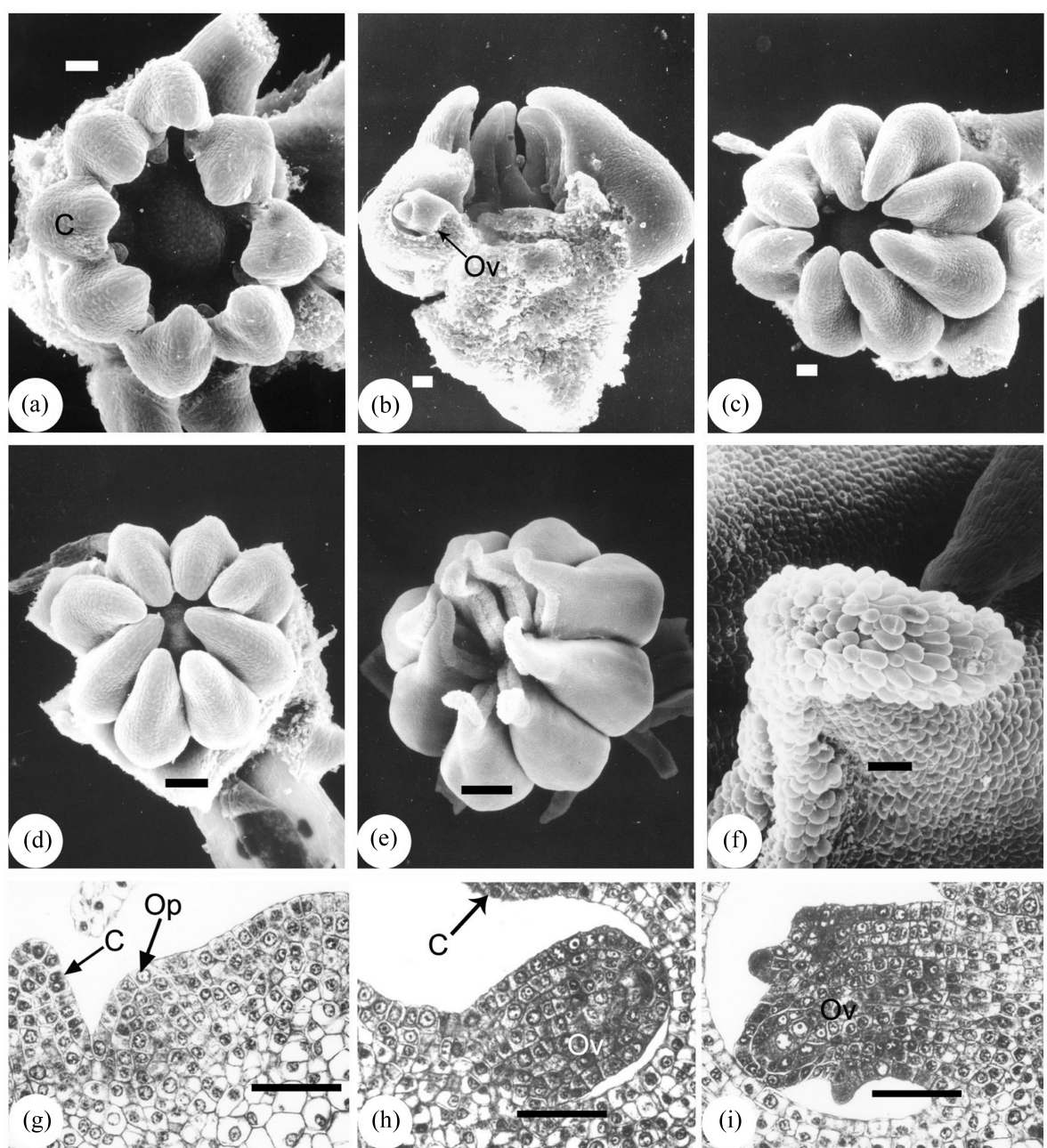

Figure 6. Developing pistil of Ph. esculenta. (a)-(e) Pistil was developing, how to form apocapous; (f) Stigma. Bar $=50 \mu \mathrm{m}$.

tem forming. This pause allows everywhere can initiate androecium on the ring meristem. The place is random where the first androecium initiated on, so that androecium located opposite or alternate with sepal just is a random phenomenon. Carpel originated follow on androecium and no any pause between them. And carpel also originated simultaneously, which originated on ring meristem evidently. The ovule originated when carpel was forming, and also originated simultaneously. So that androecium, carpel and ovule were thought originated on ring meristem, and this phenomenon maybe imply that Phytolaccaceae is one more evolutionary group. In Passiflora lobata, which is a more evolutionary group in Dilleniideae, androecium and carpel originated on ring meristem evidently [18].

Why is the flower with 5-merous or 3-merous? This question was discussed by different author, someone think that accord with Fibonacci sequence [19]. And Nishiyama (2004) thought that 5-merous is more stable, rather than by way of Fibonacci sequence [20]. In Phytolacca, 5-merous, 8-merous and 10-merous, or more were seen, this phenomenon maybe caused by ring meristem.

\subsection{Centrifugal Development Androecium}

In these species which have multitude stamens, the androecia developed in centrifugal sequence. Leins (1994) thought that the base group of Caryophyllales should be Cactaceae and Aizoaceae, which via Paeoniaceae connected with Magnoliidae and Dilleniidae [11] [21]. But in Phytolaccaceae, androecia were not fascicled, and have no corresponding relationship with sepal. If Cactaceae and Aizoaceae are the base group of Caryophyllales, 
how did Phytolaccaceae derive from them or their ancestor? The differences between Phytolacca androecium’s initiation and rotational or helix initiation in other taxa should be paid attention on. Inner rotational androecium initiated out-of-order and so do outer rotational in plants of genus Phytolacca, so it is different from other centrifugal initiation. The androecia of Phytolacca initiated on ring meristem, and because the ring meristem extended, the lower tissue of inner androecium could initiate androecium. The ring meristem initiated androecium in infinitive numerous. So that multiple numerous of androecium and centrifugal initiation all caused by ring meristem activated, and that is no same significance with other taxa which have same features.

\subsection{Initiation and Development of Carpel}

It was proved that the carpel of Phytolacca initiated alternately with inner androecia or with androecia while single rotation [12] [22]. Is there any apocarpous pistil plant in Phytolacca? Some studies had shown there is no true apocarpous in the genus [22] [23]. There is no evident difference between apocarpous and syncarpous at initiation stage in this genus, but at its development later, because septum developed differently in different species, formed apocarpous or syncarpous, so that apocarpous and syncarpous have no same evolutionary significance in this genus and other taxa. So that couldn't say apocarpous is original or evolutionary. These two types of carpel maybe derived parallel from their common ancestor. Scheappi (1936) thought pistil with 8 carpels is similar to Illiciaceae, so guessed that the genus has some relationship with it [24]. Endress (2001) investigated the flower organogenesis of Illiciaceae [25], the floral initiation and development is different completely in Phytolacca and Illicia, only with same numerous of carpel. So Rohweder's opinion [22] Phytolaccaceae has no directly relationship with Illiciaceae should be support.

After carpel initiated, ovule initiate on the inside ring meristem of carpel, this is a special character. As a structure of carpel, ovule should initiate on carpel after it to be certain size; and this is the general regulation so far. This phenomenon of ovule initiation in Phytolacca brought to mind the arguments on cauli-ovule [26] or phyllo-ovule [24] [25] [27] in it last century. Perhaps, the features of ovule initiation are helpful to treat the arguments.

\subsection{The Origin of Caryophyllales and the Systematic Site of Phytolaccaceae in It}

Due to plants of genus Phytolacca with special characters (androecium is multiple; carpel separated and numerous), so that the systematic site of Phytolaccaceae was paid more attentions. In recent years, many studies founded different opinion on its systematic site. Manhart \& Rettig (1994), Rettig et al. (1992), Downie \& Palmer (1994) didn't support the opinion which thought the family Phytolaccaceae is the basal group of Caryophyllidea [28]-[39]. Zheng et al. (2004) via to study the floral organogenesis of genus Phytolacca, thought the family Phytolaccaceae still was basal group of Caryophyllales [40]. Rodman (1994) thought family Cactaceae and Aizoaceae was the basal group, while the family Phytolaccaceae was a more evolutionary group [41].

Many botanists expected to determine the ancestor of Caryophyllales, they speculated that it may be derived from Magnoliidea, Ranuculales or Dilleniidea, but there was no enough evidence, so did us. To investigate the androecium organogenesis of genus Phytolacca, the results show it is impossible that Caryophyllales derived from Dilleniidea or has close relationship with it. Although the androecium of Phytolacca is centrifugal, but it is different from Dilleniidea, its androecium initiated at ring meristem. Its number of stamen is much less than original group of Dilleniidea, and there is no evidently whorl or fascicle, and not evidently in sequence on time. The initiation of androecium of original plant in Dilleniidea usually divided into five districts, and the androecia united together at base in same district.

\section{Acknowledgements}

We thank lab technician Xiao Yinhou and Yang Xuejian of Key Laboratory of Systematic and Evolutionary Botany for their help. Our thanks go to Miss Yu Liying of Medicine Botanical Garden of Guangxi Province and to Mr. Zhao Mingshui of Tianmu Mountain Nature Conservation District for providing materials. This study was supported by Doctor Foundation of Shaanxi Xueqian Normal University (2014DS012).

\section{References}

[1] Mabberiey, D.J. (1987) The Plant Book. Cambridge University Press, Cambridge. 
[2] Willis, J.C. (1966) A Dictionary of the Flowering Plants and Ferns. 7th Edition, Cambridge University Press, Cambridge, 1214.

[3] Walter, H. (1909) Phytolaccaceae. Wilhelm Engelmann, Leipzig.

[4] Heimerl, A. (1934) Phytolaccaceae. In: Engler, A. and Prantl, K., Eds., Die Natürlichen Pflanzenfamilien, Wilhelm Engelmann, Leipzig.

[5] Rohwer, J.C. (1993) Phytolaccaceae. In: Kubitzki, K., Rohwer, J.G. and Bittrich, V., Eds., The Families and Genera of Vascular Plants II, Springer-Verlag, Berlin, 506-515.

[6] Eichler, A.W. (1878) Blüthendiagramme II. Wilhelm Engelmann, Leipzig.

[7] Heimerl, A. (1889) Phytolaccaceae. In: Engler, A. and Prantl, K., Eds., Die Natürlichen Pflanzenfamilien, Wilhelm Engelmann, Leipzig, 1-14.

[8] Walter, H. (1906) Die Diagramme der Phytolaccaceen. Botanische Jahrbücher Systematik, 37, 1-57.

[9] Friedrich, H.C. (1956) Studen üben die natürliche Verwandtschaft der Plambaginales und Centrspermae. Phyton (Austria), 6, 220-263.

[10] Leins, P. (1994) Putative Origin and Relationships of the Order from the Viewpoint of Developmental Flower Morphology. In: Behnke, H.-D. and Mabry, T.J., Eds., Caryophyllales: Evolution and Systematics, Springer-Verlag, Berlin, 303-316.

[11] Leins, P. and Erbar, C. (1994) Flowers in Magnoliidae and the Origin of Flowers in Other Subclasses of the Angiosperms. II. The Relationships between Flowers of Magnoliidae, Dilleniidae, and Caryophyllidae. Plant Systematics and Evolution (Historical Archive), 8, 209-218.

[12] Ronse Decraene, L.P., Vanvickenroye, P.E. and Smets, F. (1997) A Study of Floral Morphological Diversity in Phytolacca (Phytolaccaceae) Based on Early Floral Ontogeny. International Journal of Plant Sciences, 158, 57-72. http://dx.doi.org/10.1086/297414

[13] Ronse Decraene, L.P. and Smets, E. (1993) The Distribution and Systematic Relevance of the Androecial Character Polymery. Botanical Journal of the Linnean Society, 113, 285-350. http://dx.doi.org/10.1111/j.1095-8339.1993.tb00341.x

[14] Ronse Decraene, L.P. and Smets, E. (1994) Merosity in Flowers: Definition, Origin and Taxonomic Significance. Plant Systematics and Evolution (Historical Archive), 191, 83-104. http://dx.doi.org/10.1007/BF00985344

[15] Nishino, E. (1993) Floral Development in Some Species of Phytolacca with Special Reference to the Androecium. 15th International Botanical Congress, Yokohama, 22 August-3 September 1993, 338.

[16] Chen, D. and Wang, Q. (2004) Pentamerous Flowers in the Genus Phytolacca Have Been Derived from Trimerous Flowers-New Evidence from the Floral Organogenesis of Phytolacca dodecandra. Acta Phytotaxonomica Sinica, 42, 345-351.

[17] Tucker, S.C. (2003) Floral Ontogeny in Swartzia (Leguminosae: Papilionoideae: Swartzieae): Distribution and Role of the Ring Meristem. American Journal of Botany, 90, 1271-1292. http://dx.doi.org/10.3732/ajb.90.9.1271

[18] Prenner, G. (2014) Floral Ontogeny in Passiflora lobata (Malpighiales, Passifloraceae) Reveals a Rare Pattern in Petal Formation and Provides New Evidence for Interpretation of the Tendril and Corona. Plant Systematics and Evolution, 300, 1285-1297. http://dx.doi.org/10.1007/s00606-013-0961-0

[19] Dong, X.Y., Liu, Z., Saunders, R.M.K. and Chen, Z.D. (2012) Floral Ontogeny of Schisandra chinensis (Schisandraceae): Implications for Androecial Evolution within Schisandra and Kadsura. Plant Systematics and Evolution, 298, 713-722. http://dx.doi.org/10.1007/s00606-011-0581-5

[20] Nishiyama, Y. (2004) Why Is a Flower Five-Petaled? Journal of Science Education and Technology, 13, 107-114. http://dx.doi.org/10.1023/B:JOST.0000019643.64505.88

[21] Erbar, C. and Leins, P. (1994) Flowers in Magnoliidae and the Origin of Flowers in Other Subclasses of the Angiosperms. I. The Relationships between Flowers of Magnoliidae and Alismatidae. Plant Systematics and Evolution (Historical Archive), 8, 193-208.

[22] Rohweder, O. (1965) Centrispermen-Studien 2. Entwicklung und morphologische Deutung des Gynöcium bei Phytolacca. Botanische Jahrbücher für Systematik, 84, 509-526.

[23] Zheng, H.C., Hu, Z.H. and Lu, A.M. (2003) An Investigation on the Ovary Structure of Phytolaccaceae. Acta Botanica Boreali-Occidentalia Sinica, 23, 1195-1201.

[24] Schaeppi, H. (1936) Zur Morphologie des Gynoeceums der Phytolaccaceen. Flora, 131, 41-59.

[25] Endress, P.K. (2001) The Flowers in Extant Basal Angiosperms and Inferences on Ancestral Flowers. International Journal of Plant Sciences, 162, 1111-1140. http://dx.doi.org/10.1086/321919

[26] Hagerup, O. (1936) Zur Abstammung einiger Angiospermen durch Gnetales und Coniferæ, II. Centrospermae. Biolo- 
giske Meddelelser. Kongelige Danske Videnskabernes Selskab, 13, 1-60.

[27] Eckardt, T. (1954) Morphologische und systematische Auswertung der Placentation von Phytolaccaceen. Berichte der Deutschen Botanischen Gesellschaft, 67, 113-128.

[28] Dahlgren, R. (1980) A Revised System of Classification of the Angiosperms. Botanical Journal of the Linnean Society, 80, 91-124. http://dx.doi.org/10.1111/j.1095-8339.1980.tb01661.x

[29] Takhtajian, A. (1980) Outline of the Classification of Flowering Plant (Magnoliophyta). The Botanical Review, 46, 225-359. http://dx.doi.org/10.1007/BF02861558

[30] Takhtajian, A. (2009) Flowering Plants. Springer-Verlag, Berlin, 129-166.

[31] Cronquist, A. (1981) An Integrated System of Classification of Flowering Plants. Columbia University Press, New York, 248-250.

[32] Rettig, J.H., Wilson, H.D. and Manhart, J.R. (1992) Phylogeny of the Caryophyllales: Gene Sequence Data. Taxon, 41, 201-209. http://dx.doi.org/10.2307/1222329

[33] Cronquist, A. and Thorne, R.F. (1994) Nomenclatural and Taxonomic History. In: Behnke, H.-D. and Mabry, T.J., Eds., Caryophyllales: Evolution and Systematics, Springer-Verlag, Berlin, 5-25.

[34] Downie, S.R. and Palmer, J.D. (1994) A Chloroplast DNA Phylogeny of the Caryophyllales Based on Structural and Inverted Repeat Restriction Site Variation. Systematic Botany, 19, 236-252. http://dx.doi.org/10.2307/2419599

[35] Manhart, J.R. and Rettig, J.H. (1994) Gene Sequence Data. In: Behnke, H.-D. and Mabry, T.J., Eds., Caryophyllales: Evolution and Systematics, Springer-Verlag, Berlin, 236-245.

[36] APG (1998) An Ordinal Classification for the Families of Flowering Plants. Annals of the Missouri Botanical Garden, 85, 531-553. http://dx.doi.org/10.2307/2992015

[37] APG (2003) An Update of the Angiosperm Phylogeny Group Classification for the Orders and Families of Flowering Plants: APG II. Botanical Journal of the Linnean Society, 141, 399-436. http://dx.doi.org/10.1046/j.1095-8339.2003.t01-1-00158.x

[38] APG (2009) An Update of the Angiosperm Phylogeny Group Classification for the Orders and Families of Flowering Plants: APG III. Botanical Journal of the Linnean Society, 161, 105-121. http://dx.doi.org/10.1111/j.1095-8339.2009.00996.x

[39] Wu, Z.Y., Lu, A.M., Tang, Y.C., Chen, Z.D. and Li, D.Z. (2002) Synopsis of a New "Polyphyletic-Polychronic-Polytopic” System of the Angiosperms. Acta Phytotaxonomica Sinica, 40, 289-322.

[40] Zheng, H.C., Lu, A.M. and Hu, Z.H. (2004) Floral Organogenesis in Phytolacca (Phytolaccaceae). Acta Phytotaxonomica Sinica, 42, 352-364.

[41] Rodman, J.E. (1994) Cladistic and Phenetic Studies. In: Behnke, H.-D. and Mabry, T.J., Eds., Caryophyllales: Evolution and Systematics, Springer-Verlag, Berlin, 279-301. http://dx.doi.org/10.1007/978-3-642-78220-6 13 
Scientific Research Publishing (SCIRP) is one of the largest Open Access journal publishers. It is currently publishing more than 200 open access, online, peer-reviewed journals covering a wide range of academic disciplines. SCIRP serves the worldwide academic communities and contributes to the progress and application of science with its publication.

Other selected journals from SCIRP are listed as below. Submit your manuscript to us via either submit@scirp.org or Online Submission Portal.
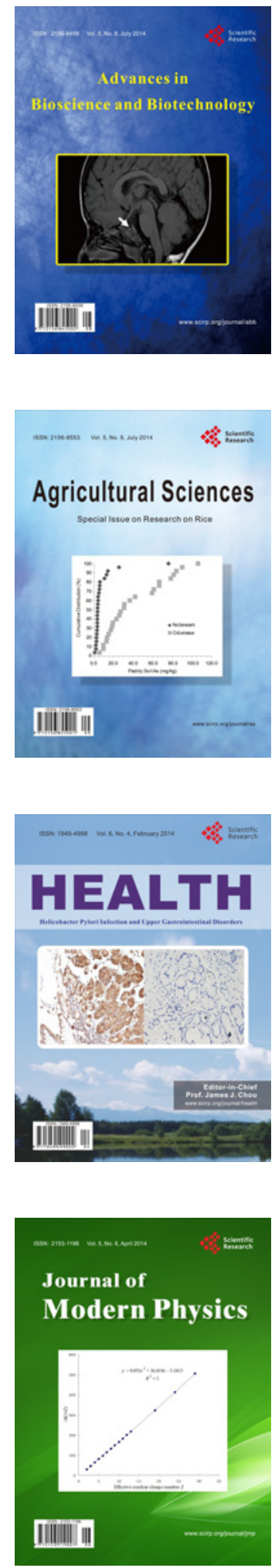
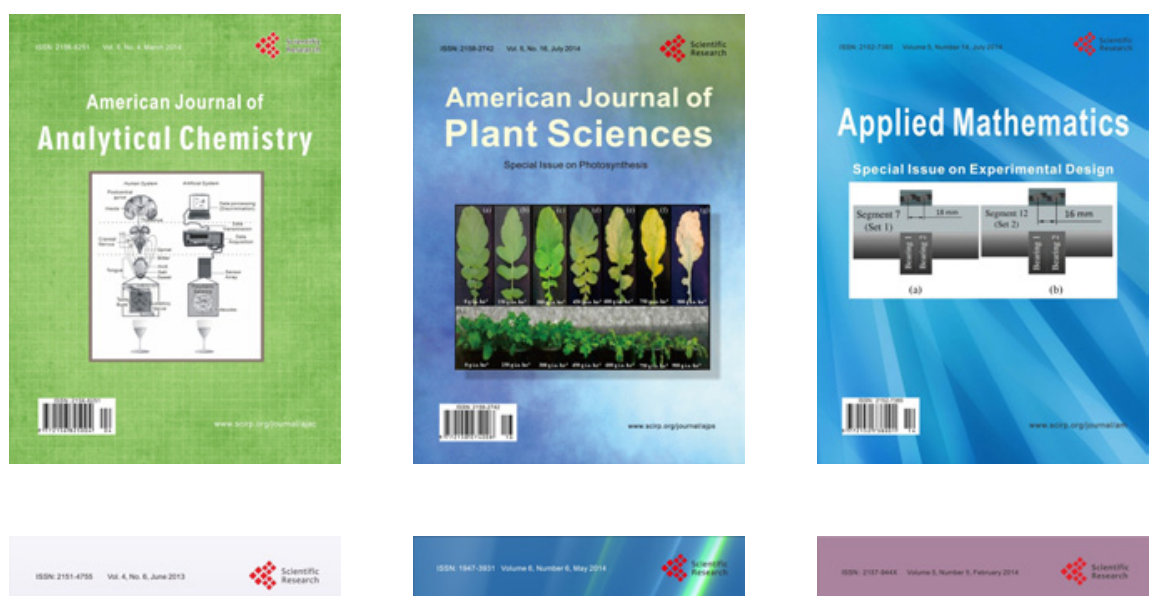

Creative Education
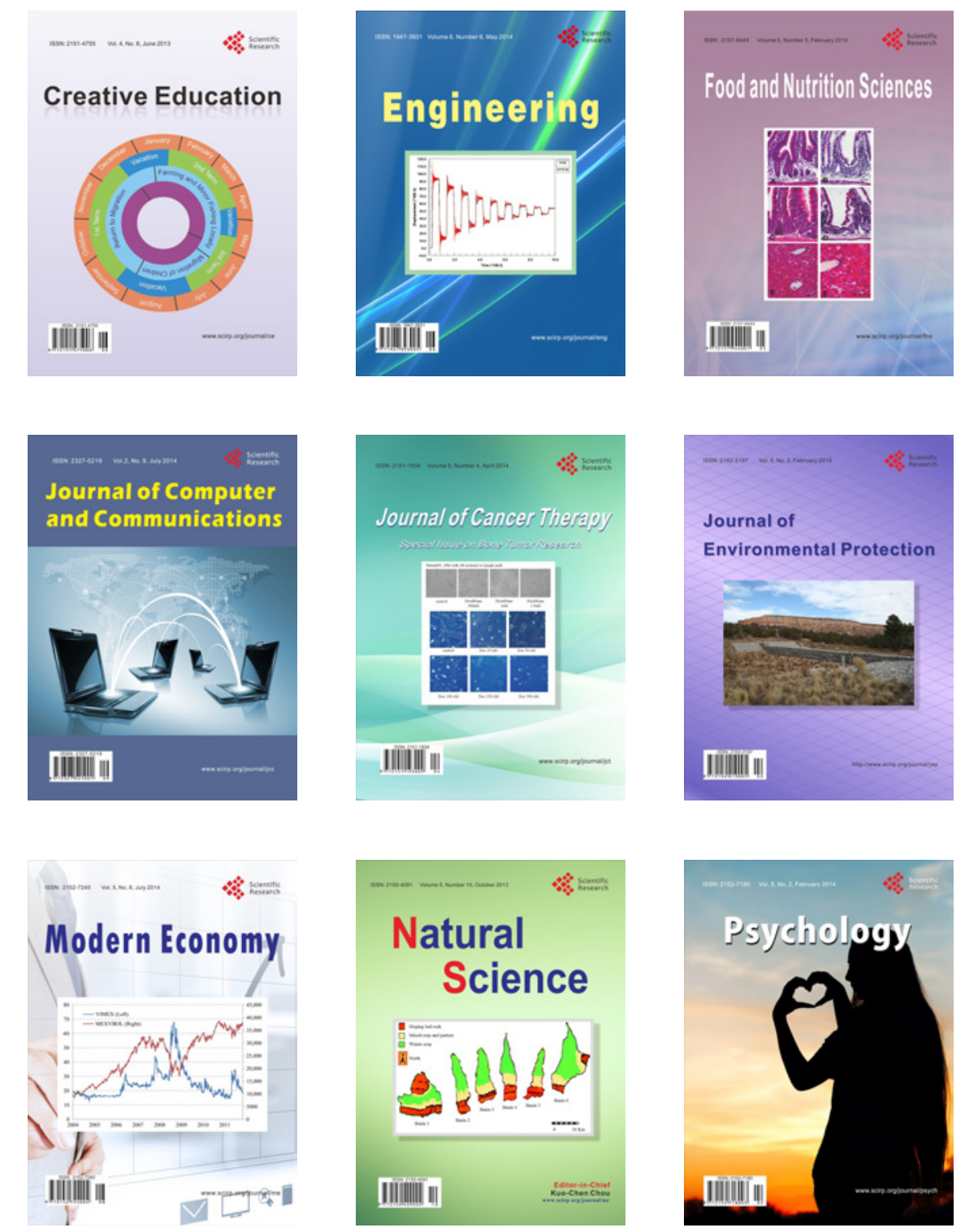